DOI 10.38129/Ann.Yur.Ist.2019.3.1.2.10

УДК 329.532 .3

\title{
МЕТРИЧНА КНИГА СВЯТО-УСПЕНСЬКОЇ ЦЕРКВИ ЗА 1839-1855 pp. ЯК ДЖЕРЕЛО ДОСЛІДЖЕННЯ ГРОМАДЯНСЬКОГО СТАНУ ЛЮДИНИ В БАРСЬКОМУ РЕГІОНІ У 30-50-х РОКАХ ХІХ СТОЛІТТЯ
}

\author{
ОЛЕКСІЙ БАКАЛЕЦЬ (Бар, Україна)
}

Відтворюючи історичну пам'ять, формуючи інтерес до спадщини народу, залучаючи молодь до державного будівництва, український народ, за словами видатного українського історика Ісидора Нагаєвського, «сповняє свою неповторну місію. I чим більше він виростить відданих синів і дочок та творить свою власну духовну і матеріальну культуру, він виконує неповторну історичну місію» $[1, \mathrm{c.2}]$.

Історичні джерела: речові, письмові, усні, зображальні, лінгвістичні, топонімічні відіграють важливу роль в об'єктивному висвітленні української історії, культури, історії церкви, регіональної історії, генеалогічних, релігійних, етнічних процесів. Письмові джерела $\epsilon$ матеріальними носіями письмової інформації про людей та суспільство: літописи, хроніки, житія, грамоти, універсали, скарги, законодавчі акти, ділові документи, метричні та актові книги, статистичні джерела, переписи населення, матеріали соціологічних досліджень, преси, судово-слідчі документи, документи громадських об'єднань та політичних партій, мемуари, записні книжки, приватне листування, подорожні нотатки іноземців, автобіографії, агіографічна, наукова та художня література [1, с. 9].

Відомий історик, вчений, державний діяч, автор магістерської дисертації «Барське староство. Історичні нариси XV - XVIII ст.» (1894р.) М. C. Грушевський (1866-1934) дав блискучий приклад наукового використання творів давньоукраїнських літописців, зарубіжних істориків, хронік, архівних документів для створення історії українського народу, а також Барського краю [2]. Здійснені дослідником публікації джерел не втратили значення і сьогодні. Плідно сьогодні в цьому напрямку працюють вітчизняні історики-джерелознавці: М. Варшавчик, Л. Винар, В. Смолій [3], М. Котляр, Я. Калакура, І. Войцехівська [5], Ю. Мицик, І. Гирич, М. Дмитрієнко, Л. Дубровіна, В. Сергійчук, В. Солдатенко, Б. Корольов, П. Толочко, В. Даниленко, В. Верстюк, В. Мордвінцев [7; 8], В. Томазов [8; 10], 
Ю. Легун [6], С. Єсюнін [4].

Серед письмових інформаційних джерел вагоме місце займають метричні книги, що містять важливу інформацію про громадянський стан людини (народження, хрещення, вінчання, смерть, відспівування) [3, с. 628]. У 260-у річницю Свято-Успенської церкви міста Бар важливо відкрити сторінки їі історії. В цьому нам допоможе метрична книга, яка велася у церкві з 1838 до 1855 року включно і яка є об'єктом нашого дослідження.

Тривалий час метричні книги, як найцінніше джерело для генеалогічних досліджень певного міста чи регіону, залишалися поза увагою професійних науковців. Такі дослідження, активізовані в незалежній Україні, сприяють введенню до наукового обігу одного із найінформативніших джерел для вивчення і відновлення родоводів [7; 8; 10].

Перші метричні книги на українських землях з'явилися у XVI ст., але систематично і повсюдно їх було запроваджено указом Петра I у 1702 р., а 3 1724 р. Синод затвердив зразок формуляра метричної книги. Їх ведення стало обов' язковим для православних священиків, а також католиків, іудеїв та лютеран. Ці книги вели священики і дяки у двох екземплярах на великих паперових аркушах.

Перший примірник метричної книги відсилався до Духовної консисторії у повітове місто, де підшивався в один великий зведений том за поточний рік.

Другий примірник книги залишався у церкві та зшивався 3 метричними книгами за попередні роки. У межах однієї парафії цілісний том виходив за $15-50$ років.

В пропонованому читацькій увазі дослідженні розглядається зміст метричної книги Свято-Успенської церкви заштатного м. Бар Могилівського повіту Подільської губернії, де збереглися записи за 18391855 роки, тобто за 16 років (див. дод. Б!). На 148 сторінках зафіксовано 210 подій (переважно вінчання) 38 січня 1839 р. до 2 жовтня 1855 р. [6].

Записи у даній книзі вели: дяки Петро Козловський (з 8 січня 1839 р. до 27 січня 1844 р.), Євстафій Твуравський (з 19 травня 1844 р. до 2 вересня 1845 р.), Петро Козловський (з 14 жовтня 1845 р. до 29 серпня 1846 р.), Євстафій Твуравський (з 6 жовтня 1846 р. до січня 1850 р.), Сильвестр Куліковський (з 5 лютого 1850 р. до 25 жовтня 1851 р.), Василь Храткович (3 жовтня 1851 р. до 1855 р.).

Частину тексту метричної книги важко прочитати через висихання чорнила та потьоки від потрапляння води на частину сторінок. Але в цілому текст доступний для ознайомлення. На жаль, не збереглися інші 
книги, де містилася цінна інформація про народження, одруження, хрещення, вінчання, смерть та відспівування місцевих жителів.

Своїми підписами завіряли правильність записів у метричній книзі наступні священники Свято-Успенської церкви: Матвій Новіцький у 18391844 рр., Тимофій Страшевский у 1844 р., Василь Кузмінський у 1844-1850 рр., Семеон Карчевський у 1850-1855 рр. [7].

Класичний запис про вінчання (затверджений у 1838 р.) сповіщає повну дату здійснення таїнства, місце мешкання, соціальний стан, ім'я по батькові, прізвище нареченого та нареченої 3 зазначенням віку, віросповідання та кількості шлюбів для наречених (для нареченої вказується ім'я батька, а в разі попереднього шлюбу - прізвище попереднього чоловіка), місце мешкання, соціальний стан, професію, імена, імена по батькові, прізвища поручителів, імена священника та причту [3, с. 628]. Цих вимог чітко дотримувалися зазначені священики та дяки (див. нижче витяги із книги).

Проаналізуємо деякі записи із метричної книги Свято-Успенської церкви заштатного міста Бар (документи передані мовою оригіналу).

«1839 года Январъ 22 дня по Указу его Императорского Величества г. Бара Успенской Церкви Священноцерковнослужители произвели обыскъ желающих вступить въ бракъ и показалось следуещее: 1. Женихъ крестьянинъ Мартын Николаев Мытковский православного исповедования, проживающий в Могилёвском уезде деревни Войнашовка в приходе сей церкви. 2. Невеста крестьянка Марта Фёдорова Ткачучка того ж исповедования, проживающая в Могилёвском уезде деревни Войнашовка в приходе сей церкви. 3. Возраст къ супружеству имеютъ совершенный, именно: Женихъ 20 лет, а невеста 18 лет, оба находятся въ здравом уме. 4. Родства между ними духовного или плотского и свойства возбраняющего по установлению Св. Церкви брак никакого нет. 5. Женихъ холость, а невеста девица. 6. К браку приступают они по своему взаимному согласию, а не по принуждению и на то имеют от родителей позволение. 7. По троекратному соглашению сделанному в означенной Церкви 1839-го года Января 5, 15 и 22 числа препятствия к сему браку никакого никемъ не объявлено. 8. Для удостоверения беспрепятственного сего брака имеется письменный документъ. 9. По сему бракосочетание означенныхъ лиц предположено совершить сего года Января 22 дня во узаконенное время при посторонних свидетеляхъ. 10. Что всё показанное уж о женихе и невесте справедливо, в томъ удостоверяютъ своей подписью как они сами, такъ и поручители, съ темъ, что если что окажется ложным, то подписавшиеся повинны за то суду по правилам церковным и Законамъ 
гражданскимъ.

Женихъ Крестьянинъ Мартын Николаев Мытковский

Невеста Крестьянка Марта Фёдорова Ткачучка

Поручители со стороны жениха крестьяне деревни Войнашовки: Николай Андреевъ Паращук и Никита Павлов Захарчукъ. Со стороны невесты: Григорий Андреев Ткачукъ и Петр Павлов Захарчукъ крестьяне той же деревни.

Обыскъ сей производили: Свяшенникъ Матвий Новицкий

Дьякъ Пётръ Козловский» [6, с. 5-7].

3 іншого запису про вінчання ми дізнаємося про наступне: «1849 года Августа 26 дня по Указу его Императорского Величества Заштатного г. Бара Успенской Церкви Священноцерковнослужители произвели обыскъ желающих вступить въ бракъ показалось следуещее: Женихъ Винницкого уезда Титулованный советникъ Иванъ Николаевъ Лазавский, Православного исповедования. 2. Невеста Отставного генерал-маёра Антона Иванова Бачинского дочь Юлия Ригина, жительствует въ Хуторахъ. 3. Возраст къ супружеству имеютъ совершенный, именно: Женихъ 33 г., а невеста 16 лет, оба находятся въ здравом уме. 4. Родства между ними духовного или плотского родства и свойства возбраняющего по установлению Св. Церкви брак никакого нет. 5. Женихъ холость, а невеста девица. 6. К браку приступают они по своему взаимному согласию, а не по принуждению и на то имеют от родителей позволение. 7. По троекратному соглашению сделанному в монастырской Церкви 1849 года Августа 20, 22 и 26 числа препятствия к сему браку никакого никемъ не объявлено. 8. Для удостоверения беспрепятственного сего брака имеется письменный документъ. 9. По сему бракосочетание означенныхъ лиц предположено совершить сего года Августа 26 дня во узаконенное время при посторонних свидетеляхъ.

Женихъ Иванъ Николаевъ Лазавский

Невеста Юлия Ригина

Поручители за жениха: помещикъ Стиранъ Маевский, Кочинская Динария и Кавалеръ Думский, по невесте: помещикъ Петр Одвенский, помещикъ Долинский Василий

Свяшенникъ Симеон Карчевский

Протоиерей Василий Кузьмин

Дияконъ Иеофан Тыривский» [6, с. 69].

У третьому документі, датованому 15 жовтня 1850 р. записано: «1850 года Октября 15 дня по Указу Его Импрераторского Величества города Бара Успенской Церкви Священной Церковнослужители производили обыскъ о 
желающих вступить въ бракъ и оказалось следующее: 1. Женихъ Барский мещанинъ Александръ Ивановъ Манита, православный, жительствуетъ в приходе сей Церкви. 2. Невеста Барская мещанка Агнесса Варикова Прохницка Римского обряда, жительствуетъ в приходе Барского Костёла. 3. Возраст къ супружеству имеютъ совершенный, а именно: женихъ 20 лет, невеста 18 лет и оба находятся в здравом уме. 4. Родства между ними духовного или плотского родства и свойства возбраняющего по установлению Св. Церкви брак никакого нет. 5. Женихъ холостъ, а невеста девица. 6. К браку приступают они по своему взаимному согласию, а не по принуждению и на то имеют от родителей позволение. 7. По троекратному соглашению сделанному в монастырской Церкви сего года и октября 1, 8 и 15 дней препятствия к сему браку никакого никемъ не объявлено. 8. Для удостоверения беспрепятственного сего брака имеется письменный документъ. 9. По сему бракосочетание означенныхъ лиц предположено совершить в Монастыре сего года октября 15 дня во узаконенное время при посторонних свидетеляхъ. 10. Что всё показанное уж о женихе и невесте справедливо, в томъ удостоверяютъ своей подписью как они сами, такъ и поручители, съ темъ что если что окажется ложным, то подписавшиеся повинны за то суду по правилам церковным и законамъ гражданскимъ.

Женихъ Мещанинъ Александръ Ивановъ Манита

Невеста Мещанка Агнесса Ваврикова Прохницка

Поручители за жениха: барские Мещане Андрей Никитинъ Матвеенко и Иванъ Онуфриев Манита, по невесте: Яковъ Ивановъ Ходзинский и бывший крестьянин Успенской юридики Тарасий Яковлевъ Поворознюкъ.

Обыскъ сей производили: Свяшенникъ Симеон Карчевский Дияконъ Иеофан Тыривский» [6, с. 102].

Розглянувши частину записів про одруження із метричної книги Свято-Успенської церкви м. Бара за 1839-1855 рр. можна зробити деякі висновки.

По-перше, нами встановлено, що середній вік «женихів» у Барі та навколишніх селах у 30-50-х роках становив 28 років, а «наречених» - 25 років (враховуючи повторні шлюби для вдів та вдівців) (див дод. В).

По-друге, серед осіб, які укладали шлюб і проходили обряд вінчання, переважають православні і лише декілька разів зафіксовані випадки одруження православних із римо-католиками.

По-третє, у ролі поручителів (свідків) виступають селяни, міщани, офіцери та дворяни, переважно місцеві поміщики (див. дод. Б).

По-четверте, переглянувши прізвища наречених, їх поручителів та 
церковнослужителів, які реєстрували шлюб, можна серед сучасних мешканців міста Бар, сіл Войнашівка, Шпирки, Шершні та інших віднайти подібні прізвища. Приклади: Митковський, Матковський, Попик, Нетупський, Маніта, Прохніцький, Юзвенко, Нікітін, Бортник, Мацюк, Кащенко, Ришовський, Гвоздецький, Блащук, Гуд, Захарчук, Якубчик, Ходзінський, Кремінський, Слободянюк, Ткачук, Барчук, Тихолаз, Царенко, Максімов, Матвієнко, Карчевський, Козловський та інші (див. дод. Г).

\section{Соціальний, національний склад та динаміка чисельності населення} м. Бар Подільської губернії в 1861 - 1913 рр. (за даними С. М. Єсюніна)

\begin{tabular}{|c|c|c|c|c|c|c|c|c|c|c|}
\hline \multirow[b]{2}{*}{ Рік } & \multirow[b]{2}{*}{$\begin{array}{c}\text { Динаміка } \\
\text { чисельності }\end{array}$} & \multicolumn{5}{|c|}{$\begin{array}{c}\text { Становий } \\
\text { склад }\end{array}$} & \multicolumn{4}{|c|}{$\begin{array}{c}\text { Національний } \\
\text { склад }\end{array}$} \\
\hline & & 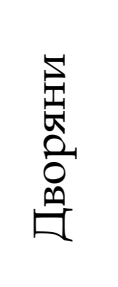 & 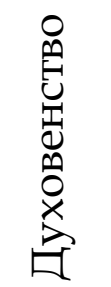 & 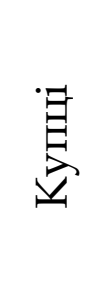 & 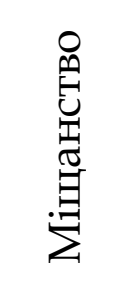 & 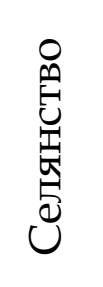 & 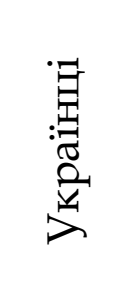 & : & 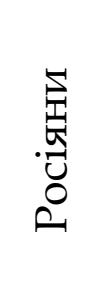 & 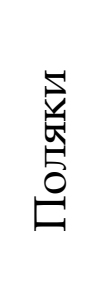 \\
\hline 1861 & 7274 & $\begin{array}{c}133 \\
1,9 \%\end{array}$ & $\begin{array}{c}58 \\
0,8 \%\end{array}$ & $\begin{array}{r}384 \\
5,3 \%\end{array}$ & $\begin{array}{c}6317 \\
86,8 \%\end{array}$ & $\begin{array}{c}194 \\
2,7 \%\end{array}$ & - & - & - & - \\
\hline 1881 & 11566 & - & - & - & - & - & - & - & - & - \\
\hline 1897 & 9982 & $\begin{array}{c}232 \\
2,3 \%\end{array}$ & $\begin{array}{c}48 \\
0,5 \%\end{array}$ & $\begin{array}{c}78 \\
0,8 \%\end{array}$ & $\begin{array}{c}8658 \\
86,7 \%\end{array}$ & $\begin{array}{r}809 \\
8,1 \%\end{array}$ & $\begin{array}{l}3332 \\
33,4 \%\end{array}$ & $\begin{array}{c}5764 \\
57,7 \%\end{array}$ & $\begin{array}{r}485 \\
4,9 \%\end{array}$ & $\begin{array}{c}378 \\
3,8 \%\end{array}$ \\
\hline 1913 & 22663 & - & - & - & - & - & - & - & - & - \\
\hline
\end{tabular}




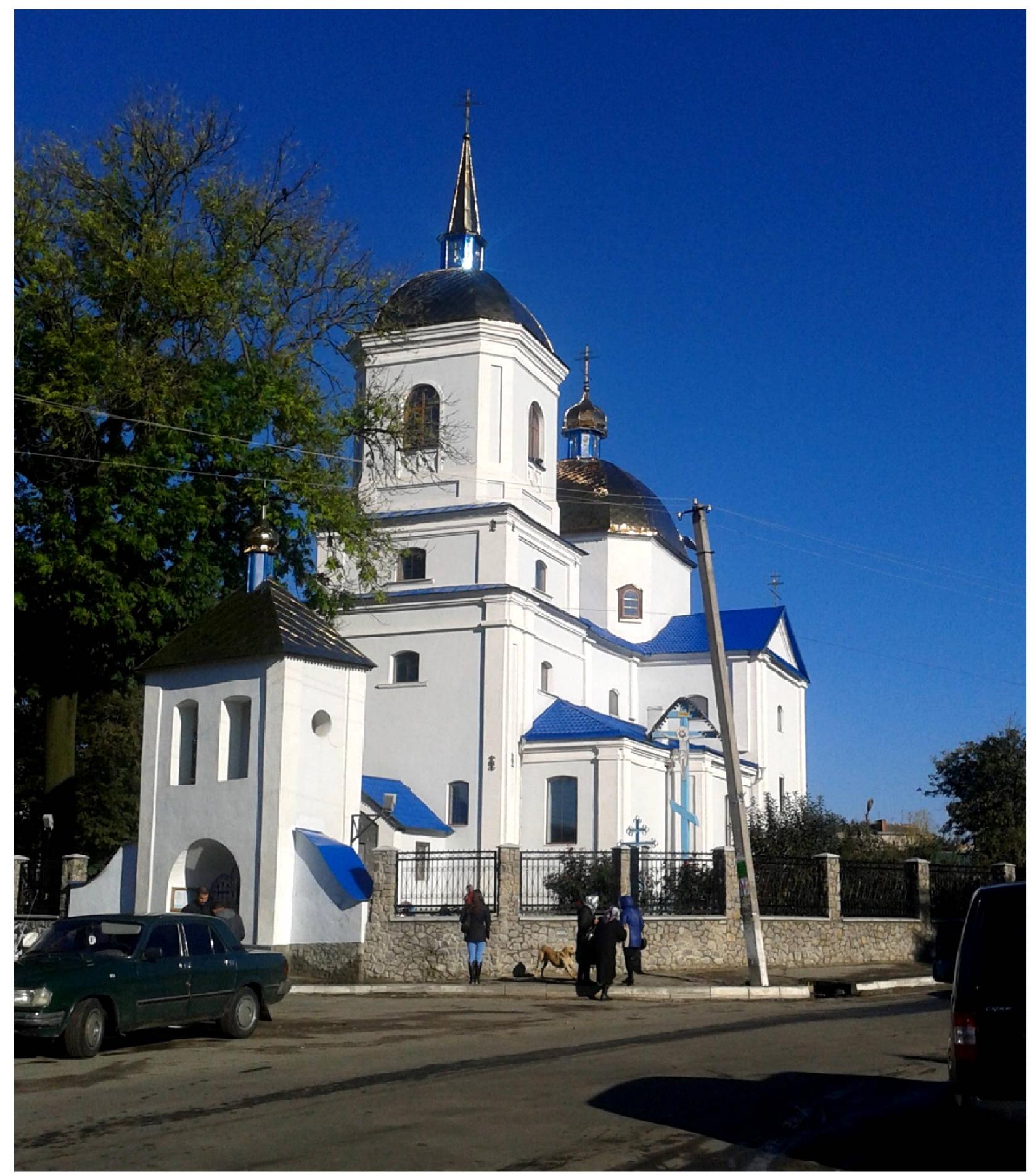




\section{Додаток Б. Запис про реєстрацію шлюбу від 15 жовтня 1850 р. в Свято-Успенській церкві м. Бар Могилівського повіту}

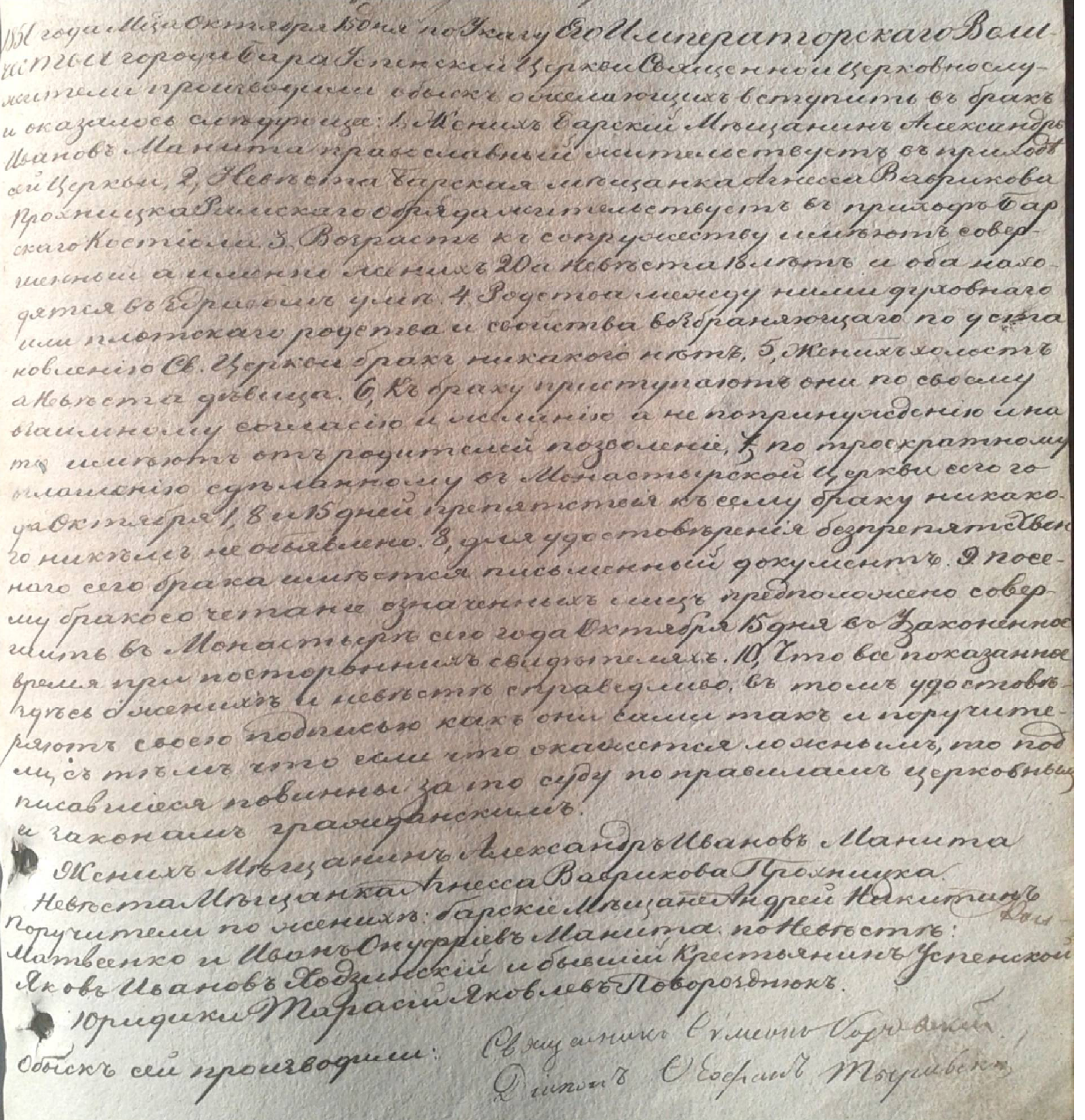


Додаток В. Відомості про віковий, соціальний, релігійний стан наречених за 1839-1855 рр. за даними метричної книги Свято-Успенської церкви м. Бар

\begin{tabular}{|c|c|c|c|c|c|c|}
\hline $\begin{array}{c}\text { № } \\
\Pi / \Pi\end{array}$ & $\begin{array}{c}\text { Ім'я, по } \\
\text { батькові, } \\
\text { прізвище }\end{array}$ & $\begin{array}{c}\text { Кіл- } \\
\text { ть } \\
\text { років }\end{array}$ & $\begin{array}{l}\text { Віроспо- } \\
\text { відування }\end{array}$ & $\begin{array}{c}\text { Соціальний } \\
\text { стан }\end{array}$ & $\begin{array}{c}\text { Місце } \\
\text { проживання }\end{array}$ & $\begin{array}{c}\text { Дата } \\
\text { вінчання }\end{array}$ \\
\hline $\mathbf{1}$ & 2 & 3 & 4 & 5 & 6 & 7 \\
\hline 1 & $\begin{array}{l}\text { Прокіп } \\
\text { Іванович } \\
\text { Поветчук } \\
\text { Агафія } \\
\text { Степанівна } \\
\text { Нечапка }\end{array}$ & 40 & Православний & Селянин & $\begin{array}{l}\text { С.Войнашівка } \\
\text { С.Войнашівка }\end{array}$ & $\begin{array}{l}8.01 . \\
1839 p .\end{array}$ \\
\hline 2 & $\begin{array}{l}\text { Петро } \\
\text { Васильович } \\
\text { Вербицький } \\
\text { Олена Іванівна } \\
\text { Кульчицька }\end{array}$ & 25 & $\begin{array}{c}\text { Православний } \\
\text { Православна }\end{array}$ & Громадянин & $\begin{array}{l}\text { М. Бар } \\
\text { М. Бар }\end{array}$ & $\begin{array}{l}15.01 . \\
1839 \mathrm{p} .\end{array}$ \\
\hline 3 & $\begin{array}{l}\text { Данило } \\
\text { Григорович } \\
\text { Чинкалюк } \\
\text { Фросина } \\
\text { Іванівна } \\
\text { Попик }\end{array}$ & 17 & Православний & Селянин & $\begin{array}{l}\text { С. Шпирки } \\
\text { С. Шпирки }\end{array}$ & $\begin{array}{l}22.01 . \\
1839 \mathrm{p} .\end{array}$ \\
\hline 4 & $\begin{array}{l}\text { Мартин } \\
\text { Миколайович } \\
\text { Митковський } \\
\text { Марія } \\
\text { Федорівна } \\
\text { Ткачук }\end{array}$ & 20 & Православна & Селянин & $\begin{array}{l}\text { С.Войнашівка } \\
\text { С.Войнашівка }\end{array}$ & $\begin{array}{l}22.01 . \\
1839 \text { p. }\end{array}$ \\
\hline 5 & $\begin{array}{l}\text { Дмитро } \\
\text { Іванович } \\
\text { Ришовський } \\
\text { Параска } \\
\text { Олексіївна } \\
\text { Бєлоусова }\end{array}$ & 21 & Православна & Міщанин & М. Бар & $\begin{array}{l}22.01 . \\
1839 \text { p. }\end{array}$ \\
\hline 6 & $\begin{array}{l}\text { Федір } \\
\text { Максимович } \\
\text { Маніта } \\
\text { Свдокія } \\
\text { Іванівна } \\
\text { Поворознюк }\end{array}$ & 20 & Православна & Міщанка & М. Бар & $\begin{array}{l}22.01 . \\
1839 \text { p. }\end{array}$ \\
\hline 7 & $\begin{array}{l}\text { Кирило Ілліч } \\
\text { Лисицький } \\
\text { Анна Яківна } \\
\text { Назаревичева }\end{array}$ & 24 & $\begin{array}{l}\text { Православний } \\
\text { Православна }\end{array}$ & Оберофіцер & $\begin{array}{l}\text { М. Бар } \\
\text { М. Бар }\end{array}$ & $\begin{array}{l}22.01 . \\
1839 \mathrm{p}\end{array}$ \\
\hline
\end{tabular}




\begin{tabular}{|c|c|c|c|c|c|c|}
\hline 1 & 2 & 3 & 4 & 5 & 6 & 7 \\
\hline 8 & $\begin{array}{l}\text { Іван } \\
\text { Федорович } \\
\text { Поветчук } \\
\text { Євдокія } \\
\text { Михайлівна } \\
\text { Василевська }\end{array}$ & 22 & $\begin{array}{c}\text { Православний } \\
\text { Православна }\end{array}$ & $\begin{array}{l}\text { Селянин } \\
\text { Міщанка }\end{array}$ & $\begin{array}{l}\text { М. Бар } \\
\text { М. Бар }\end{array}$ & $\begin{array}{l}29.01 . \\
1839 \mathrm{p}\end{array}$ \\
\hline 9 & $\begin{array}{l}\text { Петро } \\
\text { Вікентійович } \\
\text { Остапчук } \\
\text { Олена Іванівна } \\
\text { Франкова }\end{array}$ & 20 & $\begin{array}{c}\text { Православний } \\
\text { Православна }\end{array}$ & Селянин & $\begin{array}{l}\text { М. Бар } \\
\text { М. Бар }\end{array}$ & $\begin{array}{l}23.04 . \\
1839 \mathrm{p}\end{array}$ \\
\hline 10 & $\begin{array}{l}\text { Тимофій } \\
\text { Семенович } \\
\text { Глинник } \\
\text { Агафія } \\
\text { Павлівна } \\
\text { Мацюк }\end{array}$ & 45 & $\begin{array}{l}\text { Православний } \\
\text { Православна }\end{array}$ & $\begin{array}{l}\text { Рядовий } \\
\text { Уланського } \\
\text { полку } \\
\\
\text { Міщанка }\end{array}$ & $\begin{array}{l}\text { М. Бар } \\
\text { М. Бар }\end{array}$ & $\begin{array}{l}23.04 . \\
1839 \text { p. }\end{array}$ \\
\hline 11 & $\begin{array}{l}\text { Яків } \\
\text { Андрійович } \\
\text { Юзвенко } \\
\text { Марія Іванівна } \\
\text { Енецька }\end{array}$ & 35 & $\begin{array}{l}\text { Православний } \\
\\
\text { Римо- } \\
\text { католичка }\end{array}$ & Селянка & С. Ястрибці & $\begin{array}{l}25.05 . \\
1839 \text { p. }\end{array}$ \\
\hline 12 & $\begin{array}{l}\text { Іван } \\
\text { Миколайович } \\
\text { Папроцький } \\
\text { Анастасія } \\
\text { Романівна } \\
\text { Білоусова }\end{array}$ & 25 & $\begin{array}{c}\text { Римо-католик } \\
\\
\text { Православна } \\
\end{array}$ & Міщанин & $\begin{array}{c}\text { С.Вербівці } \\
\text { Ушицького } \\
\text { повіту } \\
\\
\text { М. Бар. }\end{array}$ & $\begin{array}{l}02.06 . \\
1839 \text { p. }\end{array}$ \\
\hline 13 & $\begin{array}{l}\text { Андрій } \\
\text { Михайлович } \\
\text { Бортник } \\
\text { Докія } \\
\text { Тимофіївна } \\
\text { Гримаченко }\end{array}$ & 25 & Римо-католик & Міщанин & $\begin{array}{l}\text { M. Бар } \\
\text { М. Бар }\end{array}$ & $\begin{array}{l}23.10 . \\
1840 \text { p. }\end{array}$ \\
\hline 14 & $\begin{array}{l}\text { Вікентій } \\
\text { Полікарпович } \\
\text { Нетупський } \\
\text { Марина } \\
\text { Олександрівна } \\
\text { Мошинська }\end{array}$ & 48 & $\begin{array}{l}\text { Православний } \\
\text { Православна }\end{array}$ & Громадянин & $\begin{array}{l}\text { M.Бар } \\
\text { М.Бар }\end{array}$ & $\begin{array}{l}21.08 . \\
1855 \text { p. }\end{array}$ \\
\hline
\end{tabular}


Додаток Г. Список поручителів та їх соціальний стан (складено О. Бакальцем за матеріалами метричної книги)

\begin{tabular}{|c|c|c|}
\hline № п/п & Ім'я, по батькові, прізвище & Соціальний стан \\
\hline 1 & 2 & 3 \\
\hline 1 & Андрій Шаповальчук & селянин \\
\hline 2 & Лаврін Сарачук & селянин \\
\hline 3 & Павло Балагура & селянин \\
\hline 4 & Василь Вербицький & громадянин \\
\hline 5 & Іван Степанович Кульчицький & дворянин \\
\hline 6 & Данило Чипкалюк & селянин \\
\hline 7 & Фросина Попик & селянка \\
\hline 8 & Петро Чипкалюк & селянин \\
\hline 9 & Данило Гвоздецький & селянин \\
\hline 10 & Мартин Митковський & селянин \\
\hline 11 & Марта Ткачук & селянка \\
\hline 12 & Петро Захарчук & селянин \\
\hline 13 & Дмитро Ратибський & міщанин \\
\hline 14 & Параска Білоус & міщанка \\
\hline 15 & Олексій Микитович Гуд & міщанин \\
\hline 16 & Петро Васильович Верджбіцький & громадянин \\
\hline 17 & Семен Іванович Повієнчук & селянин \\
\hline 18 & Орест Грещинський & дворянин \\
\hline 19 & Яків Іванович Ходзінський & міщанин \\
\hline 20 & Павло Блащук & селянин \\
\hline 21 & Іван Підвальський & селянин \\
\hline 22 & Іван Федорович Гвоздецький & міщанин \\
\hline 23 & Роза Валанрук & селянка \\
\hline 24 & Устим Кремінський & міщанин \\
\hline 25 & Данило Криворучко & міщанин \\
\hline 26 & Микита Черниш & міщанин \\
\hline 27 & Анастасія Слободянючка & селянка \\
\hline 28 & Іван Дмитрович Висюк & селянин \\
\hline 29 & Іван Ткач & селянин \\
\hline 30 & Іван Боршанович & міщанин \\
\hline 31 & Данило Криворучко & міщанин \\
\hline 32 & Степан Барчук & селянин \\
\hline 33 & Василь Жаврук & міщанин \\
\hline 34 & Василь Іванович Корбут & Дворянин \\
\hline
\end{tabular}




\begin{tabular}{|c|c|c|}
\hline 1 & 2 & 3 \\
\hline 35 & Степанида Балагура & селянка \\
\hline 36 & Іван Тихолаз & селянин \\
\hline 37 & Антон Мошинський & міщанин \\
\hline 38 & Яків Іванович Височанський & селянин \\
\hline 39 & Тимофій Войтков & селянин \\
\hline 40 & Ілля Захарчук & селянин \\
\hline 41 & Гнат Ткач & селянин \\
\hline 42 & Марчук & селянин \\
\hline 43 & Матрона Захарчук & селянка \\
\hline 44 & Іван Максімов & офіцер \\
\hline 45 & Ігнатій Зіжукало & Дворянин \\
\hline 46 & Іван Царенко & міщанин \\
\hline 47 & Степан Максимович Якубчик & міщанин \\
\hline 48 & Дементій Іванович Надич & селянин \\
\hline 49 & Олексій Іванович Твардовський & селянин \\
\hline 50 & Антон Якович Сіпацький & Дворянин \\
\hline 51 & Евстарх Валентинович Масєркін & Дворянин \\
\hline 52 & Василь Григорович Волощук & дворянин \\
\hline 53 & Тарас Якович Поворознюк & селянин \\
\hline 54 & Онуфрій Іванович Маніта & міщанин \\
\hline 55 & Ілля Семенович Любчик & міщанин \\
\hline 56. & Іван Іванович Блажевський & міщанин \\
\hline 57. & Федір Андрійович Глінський & селянин \\
\hline 58 & Степан Степанович Кашубейко & селянин \\
\hline 59 & Андрій Матвійович Шаповальчук & селянин \\
\hline 60 & Семен Іванович Повітчук & селянин \\
\hline 61 & Іван Федорович Повітчук & - \\
\hline 62 & Федір Андрійович Гринник & - \\
\hline 63 & Андрій Федорович Бронецький & міщанин \\
\hline 64 & Олексій Петрович Юзвенко & міщанин \\
\hline 65 & Герасим Петрович Мацюк & міщанин \\
\hline 66 & Павло Карпович Трачевський & міщанин \\
\hline 67 & Микита Іванович Сторожук & міщанин \\
\hline 68 & Лев Іванович Петров & міщанин \\
\hline 69 & Василь Павлович Качановський & міщанин \\
\hline 70 & Федір Васильович Вороновський & міщанин \\
\hline 71 & Семен Васильович Яблоцький & унтер-офіцер \\
\hline
\end{tabular}




\begin{tabular}{|c|c|c|}
\hline $\mathbf{1}$ & $\mathbf{2}$ & $\mathbf{3}$ \\
\hline 72 & Алексій Федотів & фельдфебель \\
\hline 73 & Орест Лукич Матковський & - \\
\hline 74 & Микола Степанович Перковський & дворянин \\
\hline 75 & Назарій Добранський & дворянин \\
\hline 76 & Костянтин Іванович Войтович & міщанин \\
\hline 77 & Свирид Михайлович Василевський & міщанин \\
\hline 78 & Іван Онуфрійович Маніта & міщанин \\
\hline 79 & Іван Миколайович Мірчук & селянин \\
\hline 80 & Олександр Блажеєв-Мошинський & міщанин \\
\hline 81 & Олімпія Кривіцька & міщанка \\
\hline 82 & Павло Йосипович Хмелівський & міщанин \\
\hline 83 & Пилип Гаврилович Томашевський & міщанин \\
\hline 84 & Андрій Іванович Маковський & дворянин \\
\hline 85 & Микола Андрійович Пірнаковський & дворянин \\
\hline 86 & Іван Миколайович Гинкалюк & селянин \\
\hline 87 & Семен Григорович Демчук & селянин \\
\hline 88 & Кіндрат Кащенко & міщанин \\
\hline 89 & Петро Семенович Третяк & міщанин \\
\hline 90 & міщанин \\
\hline
\end{tabular}

\section{ЛITEPATУРА}

1. Бакалець О. А. Історія України з найдавніших часів до початку XXI ст. Навчальний посібник. / О. А. Бакалець. - Львів: Магнолія, 2016.

2.Грушевський М. С. Барське староство. Історичні нариси XV - XVIII ст. / М. С. Грушевський. - Львів, 1996.

3. Енциклопедія історії України: в 10-ти т. / Редкол.: В. А. Смолій (голова). - Т.6. К.: Наукова думка, 2009.

4. Ссюнін С. М. Міста Поділля у другій половині XIX - на початку XX ст.: монографія / С. М. Ссенін. - Хмельницький: ФОП Мельник А. А., 2015.

5. Калакура Я., Войцехівська І. Істричне джерелознавство. / Я. Калакура, I. Войцехівська. - К., 2006.

6. Легун Ю. В. Генеалогія селян Подільської губернії: джерела. / Ю. В. Легун. Вінниця, 2005.

7. Метрична книга Свято-Успенської церкви м. Бара. - Бар. -1839-1855. - 148 арк.

8. Мордвінцев В. М., Томазов В. В. Метричні книги. // Українська архівна енциклопедія. - К., 2008.

9. Мордвінцев В. М. Метричні книги. // Вісник Київського університету: Історія, вип. 41. - К., 1999. 
10. Томазов В. В. Генеалогія козацько-старшинських родів: історіографія і джерела (друга половина XVII - початок XXI ст.). / В. В. Томазов. - К., 2006.

PhD Alexey Bakalets (Bar, Ukraine)

THE METRIC BOOK OF THE HOLY-USPENSKY CHURCH FOR 1839-1855. AS A SOURCE FOR THE STUDY OF THE CIVIL STATUS OF THE RESIDENTS OF THE BAR REGION

The author of the article attempted to analyze the metric book of the Holy Dormition Orthodox Church of the city of Bar for the period from 1839 to 1855, revealing the peculiarities of the social status and religious affiliation of young residents of Bar and its environs.

Key words: Metric, Metric book, Acts of Civil Status, Brides.

доц. Алексей Бакалец (Бар, Украина)

МЕТРИЧЕСКАЯ КНИГА СВЯТО-УСПЕНСКОЙ ЦЕРКВИ ЗА 1839-1855 ГГ. КАК ИСТОЧНИК ПО ИССЛЕДОВАНИЮ ГРАЖДАНСКОГО СОСТОЯНИЯ ЖИТЕЛЕЙ БАРСКОГО РЕГИОНА

Автор статьи попытался проанализировать метрическую книгу Свято-Успенской православной церкви города Бар за период с 1839 по 1855 гг., раскрывая особенности социального положения и религиозной принадлежности молодых жителей Бара и его окрестностей.

Ключевые слова: метрика, метрическая книга, акты гражданского состояния, невесты.

доц. Олексій Бакалець (Бар, Україна)

МЕТРИЧНА КНИГА СВЯТО-УСПЕНСЬКОЇ ЦЕРКВИ ЗА 1839-1855 pp. ЯК ДЖЕРЕЛО ДОСЛІДЖЕННЯ ГРОМАДЯНСЬКОГО СТАНУ ЛЮДИНИ В БАРСЬКОМУ РЕГІОНІ У 30-50-х РОКАХ ХІХ СТОЛІТТЯ

Автор статті зробив спробу прочитати та проаналізувати метричну книгу СвятоУспенської православної церкви за період з 1839 до 1855 року, що розкриває особливості соціального стану та релігійної приналежності молодих жителів м. Бара та його околиць.

Ключові слова: метрика, метрична книга, акти громадянського стану, наречені.

* Бакалець Олексій Андрійович, кандидат історичних наук, доцент кафедри iсторії, правознавства та методики навчання Глухівського національного педагогічного університету імені Олександра Довженка, здобувач Інституту історії НАН України, член НСКУ. E-mail: bakalec_alex@ukr.net. 